\title{
RENCANA PENGELOLAAN DANAU TAMBING SEBAGAI KAWASAN EKOWISATA
}

\author{
Kezia Claudya Labonda ${ }^{1)}$, B. Irwan Wipranata ${ }^{2)}$, Sylvie Wirawati ${ }^{3)}$ \\ 1)Program Studi S1 PWK, Fakultas Teknik, Universitas Tarumanagara, claudyakezia@gmail.com \\ 2) Program Studi S1 PWK, Fakultas Teknik, Universitas Tarumanagara, irwan_wipranata@yahoo.co.uk \\ 3) Program Studi S1 PWK, Fakultas Teknik, Universitas Tarumanagara, sylview@ft.untar.ac.id
}

Masuk: 01-08-2021, revisi: 02-09-2021, diterima untuk diterbitkan: 23-10-2021

\begin{abstract}
Abstrak
Danau Tambing (Rano Kalimpaa) merupakan salah satu objek wisata Taman Nasional Lore Lindu yang berpotensi untuk dikembangkan sebagai ekowisata. Akan tetapi, masih terdapat permasalahan terkait pengelolaan diantaranya fasilitas yang tersedia kurang terawat dan belum mencukupi kebutuhan wisatawan kemudian pengelolaan internal yang belum memiliki struktur organisasi yang terintegrasi. Taman Nasional Lore Lindu telah menyusun rencana induk pengembangan ekowisata pada tahun 2018 yang berfokus pada penataan dan pembangunan sarana prasarna pendukung wisata. Tujuan dari penelitian ini adalah untuk memberikan usulan rencana pengelolaan dalam implementasi rencana pengembangan agar dapat mencapai kawasan destinasi wisata yang berkembang dan berkelanjutan. Adapun kajian literatur yang digunakan dalam penyusunan usulan rencana pengelolaan yaitu prinsip ekowisata berdasarkan Undang Undang Nomor 51990 Tentang Konservasi Sumber Daya Alam Hayati Dan Ekosistemnya yang mencakup konservasi, edukasi, ekonomi, kepuasan, pemberdayaan masyarakat. Kemudian juga aspek pengelolaan pariwisata yang terdiri dari beberapa komponen antara lain organisasi, manajemen, sumber daya manusia, sarana dan prasarana, daya tarik wisata dan promosi. Penelitian ini menggunakan berbagai analisis yaitu analisis lokasi, analisis kondisi eksisting, analisis rencana fisik berdasarkan rencana pengembangan ekowisata kawasan danau tambing 2018, analisis persepsi dan preferensi pengunjung, analisis penentuan sistem pengelolaan, dan analisis rencana biaya pengelolaan. Sementara alat analisis yang digunakan yaitu deskriptif, skala likert, diagram kartesius dan benchmark. Hasil dari penelitian ini merupakan konsep Rencana Pengelolaan Kawasan Danau Tambing Sebagai Kawasan Ekowisata.
\end{abstract}

Kata kunci: ekowisata, kawasan danau, konservasi, rencana pengelolaan

\begin{abstract}
Lake Tambing (Rano Kalimpaa) is one of the attractions of Lore Lindu National Park which has the potential to be developed as ecotourism. However, there are still problems related to management, including the facilities available are poorly maintained and not sufficient for the needs of tourists, then internal management that does not have an integrated organizational structure. As a manager, Lore Lindu National Park compiled a master plan for ecotourism development in 2018 which focuses on structuring and building tourism supporting infrastructure. The purpose of this study is to provide a proposed management plan in the implementation of the development plan in order to achieve a developing and sustainable tourist destination area. The literature review used in preparing the proposed management plan is the principle of ecotourism based on Law Number 51990 concerning Conservation of Biological Natural Resources and Their Ecosystems which includes conservation, education, economy, satisfaction, and community empowerment. Then also aspects of tourism management which consists of several components including organization, management, human resources, facilities and infrastructure, tourist attraction and promotion. This study uses various analyzes, namely location analysis, analysis of existing conditions, analysis of physical plans based on ecotourism development plans for the Tambing lake area 2018, analysis of visitor perceptions and preferences, analysis of management system determination, and analysis of management cost plans. While the analytical tools used are descriptive, Likert scale, Cartesian diagrams and benchmarks. The
\end{abstract}


results of this study are the concept of the Tambing Lake Area Management Plan as an Ecotourism Area.

Keywords: lake area; ecotourism; conservation; management plan

\section{PENDAHULUAN}

\section{Latar Belakang}

Provinsi Sulawesi Tengah berlokasi dizona perbatasan wilayah Asia Oceania, dan dibatasi oleh garis maya yang disebut Wallance Line dan flora fauna disebut Wallacea. Kekayaan flora dan fauna yang berbeda dan menjadi sorotan dunia sebagai objek wisata, penelitian dan pengkajian ilmiah berupa endemic yang dilindungi dalam Taman Nasional Lore Lindu menurut SK.Menteri Kehutanan No.869/Menhut-II/2014 tentang Kawasan Hutan dan Konservasi Perairan Provinsi Sulawesi Tengah dengan total luas $215.733,70$ ha dengan potensi alam berupa hutan, pegunungan, air terjun, sungai, danau, goa hingga kebudayaan. Danau Tambing (Rano Kalimpaa) berlokasi di desa Sedoa, Lore Utara, Kabupaten Poso. Kawasan sebesar 6 ha ini terletak pada ketinggian 1700 mdpl. Merupakan bagian dan dikelola langsung oleh Balai Besar Taman Nasional Lore Lindu dan juga Pemerintah Kabupaten Poso sebagai kawasan wisata yang kaya akan flora dan fauna endemic. Beberapa aktivitas wisata yang dapat dilakukan di Danau Tambing adalah: kemping, memancing, outbound, treking di sekitar danau dan menuju gunung rorekatimbu ( \pm 5-10 menit dari tambing), wisata pendidikan lingkungan, vegetasi hutan, pengamatan burung sebagai daya tarik utama dimana pada kawasan ini terdapat 54 jenis burung yang sebagaian besar adalah jenis endemik dan berstatus dilindungi.

Banyaknya potensi kawasan yang dimiliki, masih terdapat permasalahan terkait pengelolaan mulai dari fasilitas yang kurang terawat bahkan belum mencukupi kebutuhan wisata hingga pengelolaan internal yang belum memiliki struktur organisasi yang terintegrasi berisikan pembagian tugas mengenai pengelolaan, pembiayaan, keamanan, perawatan sarana prasarana dan lain-lain. Akan tetapi, Danau Tambing melalui Taman Nasional Lore Lindu telah memiliki Rencana Induk Pengembangan Ekowisata pada tahun 2018 yang berfokus pada penataan dan pembangunan sarana pendukung wisata. Dengan ditemukannya permasalahan dan adanya rencana pengembangan, penulis termotivasi untuk melakukan penelitian dan memberikan usulan Rencana Pengelolaan Danau Tambing Sebagai Kawasan Ekowisata dalam implementasi rencana pengembangan agar dapat mencapai kawasan destinasi wisata yang berkembang dan berkelanjutan tanpa melupakan bahwa objek wisata Danau Tambing adalah bagian dari Kawasan Konservasi Taman Nasional

\section{Rumusan Permasalahan}

Kawasan Danau Tambing sebagai salah satu objek wisata alam dari Taman Nasional Lore Lindu memiliki potensi untuk dikembangkan sebagai ekowisata. Akan tetapi pada kondisi eksisting, pengelolaannya masih terbilang kurang memadai mulai dari segi pelayanan fasilitas dan komponen pelengkap pariwisata terlebih belum adanya struktur organisasi yang terintegrasi. Pihak pengelolah dalam hal ini Taman Nasional Lore Lindu telah memiliki program Rencana Pengembangan Ekowisata pada tahun 2018. Untuk mencapai optimalnya pariwisata, penataan fisik perlu disertai dengan adanya pengelolaan yang sesuai untuk mencapai wisata yang berkembang dan berkelanjutan.

\section{Tujuan}

Tujuan penelitian ini ialah sebagai berikut:

1. Mengetahui kondisi eksisting kawasan wisata Danau Tambing

2. Mengetahui Rencana Induk Pengembangan Ekowisata Danau Tambing

3. Memberikan usulan strategi Rencana Pengelolaan Ekowisata Danau Tambing 


\section{KAJIAN LITERATUR}

\section{Pariwisata}

Pariwisata adalah serangkaian aktivitas berkeliling dan berpindah dari suatu tempat ke tempat lain untuk berekreasi, menghabiskan waktu, menikmati keindahan, bersenang-senang, dan sebagainya Dengan ini, maka wisata berkaitan dengan perjalanan yang bersiwat sementara dengan tujuan untuk menikmati daya tarik dari objek yang dituju.

\section{Ekowisata}

Ekowisata adalah wisata yang mengutamakan aspek konservasi alam, pemberdayaan sosial hingga kesejahteraan ekonomi dan budaya masyarakat sekitar objek wisata. Dalam hal ini, ekowisata memberi ruang bagi pembelajaran dan pendidikan bagi masa yang akan datang. Peraturan Menteri Dalam Negeri No.33 Tahun 2009 tentang Pedoman Pengembangan Ekowisata di Daerah menyebutkan, Ekowisata ialah wisata alam yang bertanggungjawab mengutamakan faktor edukasi serta dorongan terhadap usaha- usaha konservasi sumberdaya alam, dan peningkatan penghasilan penduduk lokal. Sementara Prinsip Ekowisata pada Kawasan Konservasi berpedoman pada Peraturan yang ditetapkan bersumber dari peraturan lainnya diatur dalam Undang Undang Nomor 51990 Tentang Konservasi Sumber Daya Alam Hayati Dan Ekosistemnya terdiri dari :

1. Konservasi : sebagai sumber energi alam yang mendasar dalam pengembangan serta pengelolaan wisata alam berupa produk serta pasar yang berdasar dari alam.

2. Ekologi : kestabilan ekologi ialah perencanaan serta manajemen kawasan berkepanjangan secara ekologi.

3. Edukasi : pembelajaran area diperuntukan untuk pengelola serta wisatawan. Dengan kelestarian area dalam jangka panjang bisa berjalan dengan aktivitas pembelajaran.

4. Ekonomi : merangkul dan memberi manfaat bagi warga lokal secara langsung ataupun tidak langsung. Mulai dari keterlibatan dalam pelayanan aktivitas wisata hingga menambah pengetahuan dari turis ataupun pengelola.

5. Kepuasaan : mengandung aspek pengelolaan yang diperuntukan untuk pengunjung wisata. dengan kepuasan ialah pemenuhan harapan terhadap seluruh rangkaian wisata yang ditawarkan.

\section{Konservasi}

Konservasi adalah pemeliharaan yang memperhatikan keberadaan komponen-komponen didalamnya dan mengikuti kaidah ekologis. Konservasi mengutamakan keberlanjutan sumber daya hayati serta pelestarian supaya sumber daya tetap terjaga. Sementara menurut (Allaby, 2010) konservasi adalah pengelolaan dengan tujuan memelihara kelangsungan hidup spesies dan genetik di dalam suatu biosfer seperti fungsi dan siklus ekosistem. Bentuk konservasi terdiri dari 2 golongan, yaitu konservasi in situ, dan konservasi ek situ. Adapun prinsip konservasi menurut (Supriatna, 2014) yaitu save, study, dan use. Dengan ini pengusahaan konservasi diharapkan dapat melindungi spesies dengan tidak meninggalkan aspek manfaat (Warren, 1992)

\section{Danau}

Danau terbentuk oleh karena beberapa hal yaitu penurunan muka bumi karena tergesernya lempeng atau patahan, aktivitas gurung berapi, terbentuk aliran lava ketika erupsi, hingga pelarutan tanah kapur. Menurut (Sandy, 1985), Danau adalah sebuah cekungan di muka bumi yang mana jumlah air yang masuk lebih besar daripada yang keluar. Konsep Pengembangan kawasan Wisata Danau menurut (Sastrayuda, 2015) mengacu kepada empat konsep dasar, yaitu konsep filsafat perencanaan, konsep filsafat kenyamanan, konsep filsafat rekreasi dan konsep filsafat pemasaran. 


\section{Pengelolaan}

Pengelolaan atau management berasal dari kata to manage yang artinya mengatur, dimana pengaturan dilakukan melalui proses dan diatur berdasarkan urutan dari fungsi-fungsi manajemen. Fungsi manajemen menurut (Terry, 2010) terdiri dari 4 komponen yaitu perencanaan (planning), pengorganisasian (organizing), pengaturan pelaksanaan (actuating), dan pengawasan (controlling). Komponen Pengelolaan Pariwisata menurut (Cooper, 2005) terdiri dari attraction (atraksi), accessibility (aksesibilitas), ancilliary (organisasi), amenity (fasilitas penunjang) dan activity (aktivitas) Aspek Pengelolaan Pariwisata :

1. Organisasi: memiliki struktur organisasi yang lengkap terdokumentasi dengan penjelasan tugas, dilengkapi dengan dokumen prosedur operasional standar ataupun petunjuk penerapan kerja serta peraturan ataupun perjanjian kerja bersama

2. Manajemen: penerapan program pemeliharaan serta pengawasan sesuai kaidah konservasi serta pelestarian dengan standar peraturan perundang- undangan

3. Sumber Daya Manusia: sumber daya manusia yang kompeten dibidangnya, serta melibatkan warga lokal untuk menciptakan taraf ekonomi berkelanjutan. melakukan penilaian kinerja SDM supaya terbentuk pengawasan serta pelayanan yang berkualitas

4. Sarana Prasarana: peningkatan fasilitas untuk memenuhi kebutuhan wisatawan dan terciptanya kenyamanan berwisata

5. Daya Tarik Wisata: melindungi kelestarian, mutu serta keberlangsungan hidup kekayaan alam termasuk flora fauna didalamnya sebagai daya tarik wisata, agar mencapai konservasi serta pariwisata secara berkelanjutan

6. Promosi: mengadakan promosi untuk memperkenalkan serta memberikan pengalaman bagi wisatawan, dengan ini bisa diadakan beberapa upaya semacam periklanan lewat media cetak serta internet dan pengadaan event teratur pada kawasan wisata

\section{Pengunjung}

Pengunjung menurut karakteristik terdiri dari 2 jenis yaitu karakteristik sosial ekonomi dan karakteristik pola kunjungan (Smith J., 1989).

Karakteristik pengunjung berdasarkan social ekonomi terdiri dari jenis kelamin, usia, tempat tinggal, asal daerah, jenis pekerjaan dan pendapatan per bulan. Sementara karakteristik pengunjung berdasarkan pola kunjungan mencakup tujuan berkunjung, jumlah kunjungan, rekan berkunjung, waktu kunjungan, pengeluaran selama berkunjung

\section{METODE}

Adapun metode yang digunakan dalam penelitian ini mencakup jenis data, teknik pengumpulan data, teknik pengolahan data dan alat analisis yang digunakan. Penjelasan lebih lanjut adalah sebagai berikut:

\section{Lokasi Penelitian}

Penelitian ini dilaksanakan di Kawasan Wisata Danau Tambing yang terletak di desa Sedoa, Kecamatan Lore Utara, Kabupaten Poso, Sulawesi Tengah. 


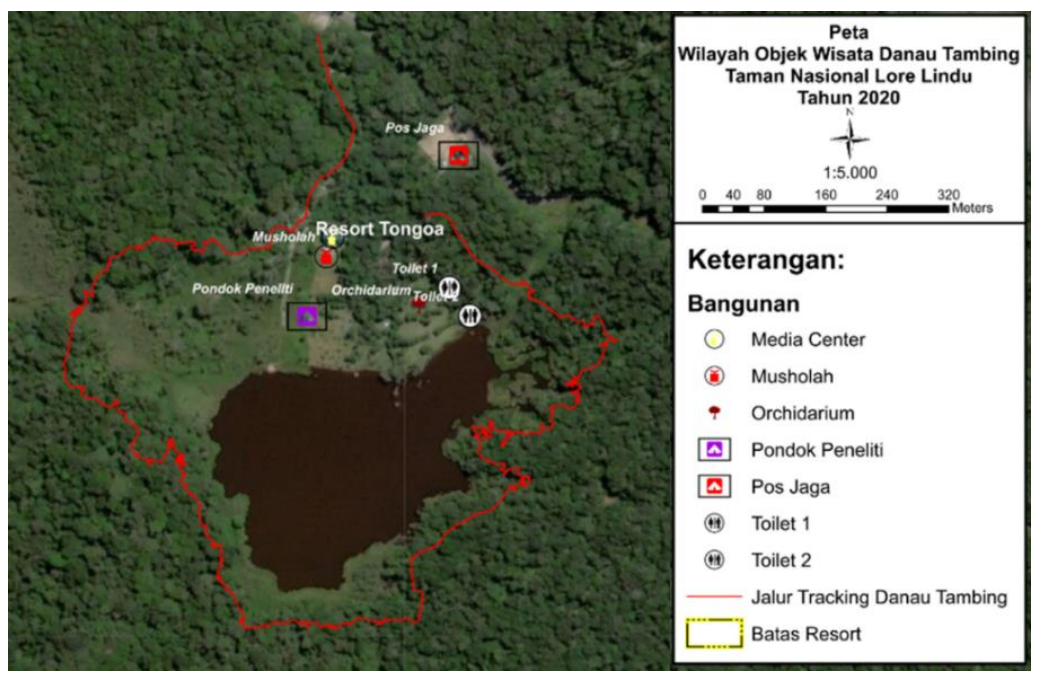

Gambar 1. Objek Wisata Danau Tambing

Sumber : Balai Besar Taman Nasional Lore Lindu, 2020

Danau Tambing (Rano Kalimpaa) berlokasi di desa Sedoa, Kecamatan Lore Utara, Kabupaten Poso dengan batasan area sebagai berikut:

- Sebelah utara : area depan kawasan berbatasan dengan jalan dan hutan

- Sebelah timur : area orchidarium dan toilet berbatasan dengan hutan

- Sebelah selatan : area danau berbatasan dengan hutan

- Sebelah barat : area kemping berbatasan dengan hutan

\section{Jenis Data}

Terdapat 2 jenis data yang digunakan dalam penelitian ini yaitu data primer dan data sekunder

1. Data Primer : pengumpulan data primer adalah teknik pengumpulan data yang dilakukan secara langsung pada objek penelitian atau sumber penelitian. Adapun pengumpulan data primer adalah untuk mengetahui aksesibilitas dan kondisi eksisting Danau Tambing.

2. Data Sekunder : pengumpulan data primer adalah teknik pengumpulan data yang dilakukan melalui sumber-sumber yang relevan dengan objek studi. Mulai dari buku, jurnal ilmiah, peraturan pemerintah, dokumen arsip, hingga internet dan media elektronik lain yang sekiranya memuat informasi terkait objek studi. Adapun pengumpulan data sekunder adalah untuk mengetahui kebijakan dan laporan pengelolaan eksisting Danau Tambing.

\section{Teknik Pengumpulan Data}

Beberapa teknik pengumpulan data yang digunakan data penelitian ini lain :

- Survey lapangan atau observasi, yaitu teknik pengumpulan data yang dilaksanakan dilaksanakan melalui pengamatan secara langsung pada lokasi penelitian untuk mengetahui fisik kawasan, ketersediaan dan kondisi fasilitas eksisting pada objek penelitian.

- Wawancara, yaitu teknik pengumpulan data yang dilaksanakan melalui tanya jawab secara lisan kepada responden. Wawancara ini dilakukan kepada pihak-pihak yang terkait dengan objek studi yang meliputi pengelola dan pekerja di Danau Tambing.

- Kuisioner, yaitu teknik pengumpulan data yang dilaksanakan melalui daftar pertanyaan yang disebarkan kepada responden untuk mendapatkan karakteristik dan tingkat kepuasan wisatawan terhadap objek studi

Populasi mengacu pada data kunjungan terbaru Wisata Danau Tambing yang diperoleh dari data statistik Balai Besar Taman Nasional yaitu pada tahun 2019. Sementara pengambilan sample menggunakan teknik random sampling atau sample acak. Responden yang akan mengisi kuesioner dalam penelitian ini adalah pengunjung Kawasan Danau Tambing dan selanjutnya akan dihitung menggunakan rumus sloving: 


$$
n=\frac{N}{1+\left(N e^{2}\right)}
$$

Keterangan :

$\mathrm{n}$ = Jumlah sampel

$\mathrm{N}=$ Jumlah populasi

$\mathrm{E}=$ Persentase tingkat kesalahan dalam pengambilan sampel

Adapun persen tingkat kesalahan dalam pengambilan sampel adalah sebesar $10 \%$, maka diperoleh perhitungan sebagai berikut :

$$
\begin{gathered}
n=\frac{4348}{1+\left(4348 \times 0,1^{2}\right)} \\
n=97,751(\text { responden })
\end{gathered}
$$

Lalu untuk memudahkan perhitungan maka jumlah sampel yang diambil dibulatkan menjadi 100 responden.

\section{Metode Pengolahan Data}

Pengolahan data terdiri dari beberapa analisis yang akan digunakan dalam penelitian. Adapun analisis yang dimaksud adalah sebagai berikut :

- Analisis Kondisi Eksisting Kawasan Danau Tambing

Analisis Kondisi Eksisting Kawasan Danau Tambing berkaitan dengan sistem pengelolaan hingga kelembagaan pengelolah. Dengan ini, dapat mengetahui kondisi eksisting pengelolaan termasuk dalamnya sarana prasarana, akomodasi hingga sumber daya manusia.

- Analisis Rencana Fisik berdasarkan Rencana Pengembangan Ekowisata Kawasan Danau Tambing 2018

Analisis ini berkaitan dengan analisis rencana penataan fisik mulai dari zonasi kegiatan, kebutuhan ruang, penataan sarana prasarana, akomodasi, dan unsur perencanaan lainnya yang tengah dirancang. Berpaut pada dokumen penataan pengembangan yang tertuang dalam Rencana Pengembangan Ekowisata Kawasan Danau Tambing 2018.

- Analisis Persepsi dan Preferensi pengunjung

Analisis Persepsi dan Preferensi pengunjung berkaitan dengan karakteristik, pandangan dan tingkat kepuasan pengunjung Kawasan Danau Tambing terhadap kondisi eksisting, Rencana Pengembangan Kawasan Danau Tambing dan pengelolaan wisata. Dengan demikian dapat dihasilkan bahan pertimbangan dalam menyusun rencana pengelolaan yang tepat.

- Analisis Penentuan Sistem Pengelolaan Kawasan Danau

Analisis Penentuan Sistem Pengelolaan Kawasan Danau ialah melakukan perbandingan dengan objek dan karakteristik yang sama untuk menjadi membanding dan contoh bagi objek penelitian yaitu Kawasan Danau Tambing, untuk menjadi acuan dalam penyusunan konsep rencana pengelolaan.

- Analisis Rencana Biaya Pengelolaan Kawasan Danau Tambing

Analisis Rencana Biaya Pengelolaan berkaitan dengan perhitungan rencana pembiayaan yang akan diterapkan dalam pengelolaan kedepannya.

Adapun metode yang digunakan dalam analisis ini adalah deskriptif, skala likert, diagram kartesius dan benchmark

\section{Alat Analisis}

Beberapa alat analisis yang digunakan dalam penelitian ini adalah deskriptif, skala likert, diagram kartesius dan benchmark 


\section{DISKUSI DAN HASIL}

\section{Analisis Kondisi Eksisting}

Menawarkan panorama indah untuk menikmati alam, aktivitas wisata yang dapat dilakukan di Danau Tambing antara lain, rekreasi, memancing, berkemah, tracking sekitar danau maupun mendaki gunung rorekatimbu, pengamatan kehidupan liar, outbound training, dan yang paling popular yaitu pengamatan burung. Danau dengan kedalaman air \pm 10 meter ini, terdapat beberapa jenis ikan mulai dari Ikan Mas, Mujair, Gabus, Sogili, Kosak, Tawes hingga Belut yang menjadi pilihan saat melaksanakan aktivitas memancing. Pada kawasan ini terdapat beberapa jenis flora dan fauna endemik seperti kantong semar yang merupakan tumbuhan karnivora di kawasan tropis yang memangsa hewan serangga atau mamalia kecil, hingga kini, terdapat 5 jenis kantong semar endemic yang merupakan spesies yang dilindungi. Kemudian juga terdapat 42 jenis koleksi anggrek yang ditampung dalam orchidarium, beberapa jenis anggrek yang dapat dijumpai pada kawasan ini antara lain Aerides odoratum, Acantheppilum javanicum Bl, Arudina bambusifolia, Cymbidium finilaysonianum. Adapun pada kawasan ini, dapat dijumpai pohon endemic ini cukup langka yaitu Eucalyptus deglupta Blume atau disebut juga pohon leda yang memiliki diameter 2 meter dan tinggi 40 meter. Selain itu, hingga kini telah tercatat 56 jenis burung didalam kawasan dengan sebagian besar adalah endemic dan berstatus dilindungi, keberadaan burung-burung ini pada kawasan menjadi daya tarik aktivitas wisata birdwatching. Satu jenis burung paling langka yang ada pada kawasan ini yaitu Kancilan buah (Hylocitrea bonensis)

\section{a. Sarana dan Prasarana}

Berikut kesimpulan dari analisis setiap sarana dan prasarana yang tersedia di Kawasan Wisata Danau Tambing.

- Parkir : terdapat lahan parkir untuk kendaraan roda 2 berkapasitas \pm 100 kendaraan dan roda $4 \pm$ 20 kendaraan, lahan parkir belum tertata dengan baik dan belum mencukupi kebutuhan saat masa liburan dan tiket parkir tidak termasuk dalam tiket masuk perorang.

- Loket : loket dilengkapi petugas yang mewajibkan pengunjung mengisi data diri, tiket setiap kegiatan terpisah dan pihak pengelola menyediakan beberapa paket wisata baik individu maupun kelompok

- Aula : terdapat 1 bangunan aula dengan ondisi bangunan cukup baik dan terawatt dan disediakan sebagai ruang diskusi bagi penelitian dan pendidikan lingkungan, penggunaan bangunan aula sudah termasuk dalam tiket masuk

- Area Kemping : lahan kemping ditengah kawasan dan terbagi menjadi 3 area dengan daya tampung \pm 1000 orang, area kemping dapat juga digunakan sebagai lokasi outbound dengan kondisi yang cukup baik selain itu pengelolah menyediakan tenda dan alas untuk disewakan kepada pengunjung, dan tiket berkemah terpisah dengan tiket masuk

- Dermaga : kondisi kurang baik dan hanya dapat menampung 10-15 orang

- Orchidarium : kondisi bangunan orchidarium cukup baik dan tidak terdapat tiket khusus untuk dapat memasuki orchidarium

- Peribadatan : terdapat 1 bangunan musholah dengan kondisi bangunan cukup baik dan dilengkapi dengan air mengalir berkapasitas \pm 35 orang

- Toilet : terdapat 2 bangunan toilet untuk umum dengan kondisi salah satu toilet cukup baik tetapi salah satu lainnya kurang terawat dan bangunan sudah using. Masing-masing toilet memiliki 4 dan 5 bilik dan dilengkapi dengan air mengalir dan tidak dikenakan uang masuk

- Gazebo : untuk kawasan wisata yang cukup luas, hanya terdapat 1 gazebo berbahan kayu dan dilengkapi atap memiliki kondisi yang kurang baik dan terletak ditengah kawasan dilengkapi dengan tempat duduk berbahan batang kayu berjumlah 14 buah

- Kebersihan : persebaran tempat sampah tidak merata dan belum ada tpa yang layak

- Listrik dan penerangan : listrik telah tersedia di kawasan wisata tetapi penerangan berupa lampu jalan masih minim

- Air Bersih : air bersih masih terbatas dan keruh,kondisi bak penampungan air bersih kurang baik. 
- Keamanan : kawasan wisata dijaga oleh polisi kehutanan yang ditugaskan oleh balai besar taman nasional lore lindu

\section{b. Organisasi Pengelola}

Kawasan Danau Tambing dikelolah langsung oleh Balai Besar Taman Nasional Lore Lindu. Termasuk dalam wilayah kerja Resort Tongoa, Bidang PTN Wilayah II Makmur Balai Taman Nasional Lore Lindu. Namun pada pengelolaan internal kawasan wisata, belum ada struktur organisasi yang terintegrasi berisikan pembagian tugas mengenai pengelolaan, pembiayaan, keamanan, perawatan sarana prasarana dan lain-lain. Selain itu juga belum terdapat standar operasional prosedur (SOP) mengenai pengelolaan sehingga hingga kini pengaturan dan pelaksanaan pengelolaan hanya berjalan dengan natural.

\section{Analisis Rencana Fisik Berdasarkan Rencana Pengembangan Ekowisata Kawasan Danau Tambing 2018}

Taman Nasional Lore Lindu (TNLL) menyusun Rencana Induk Pengembangan Ekowisata pada tahun 2018. Danau Tambing adalah sub endemic yang ditetapkan sebagai salah satu kawasan yang menjadi prioritas penataan dengan kedudukan sebagai raising star yang berperan sebagai magnet wisata, didalamnya terdapat aula, dan pusat edukasi. Adapun penambahan sarana-prasarana ini dikhususkan dengan merelokasi beberapa fasilitas yang sudah tidak dapat berfungsi, dan membangun kembali di lokasi site yang sudah diidentifikasi. Berikut kesimpulan dari masing-masing aspek :

- Parkir : lahan parkir akan dibangun kembali dengan total luas untuk lahan parkir kendaraan roda 2 sebesar $255 \mathrm{~m} 2$ dan kendaraan roda 4 sebesar $1350 \mathrm{~m} 2$

- Pusat Informasi : akan dibangun bangunan pusat informasi seluas $270 \mathrm{~m} 2$ yang dapat digunakan sebagai pusat informasi dan museum

- Retail : akan dibangun 4 gerai retail yang masing-masing seluas $12 \mathrm{~m}^{2}$ yang dapat difungsikan UMKM berjualan kebutuhan dan oleh-oleh khas Sulawesi Tengah

- Restoran : akan dibangun restoran dengan luas $96 \mathrm{~m} 2$ dibangun untuk area dapur dan makan bagi wisatawan

- Toilet : bangunan toilet pada eksisting ditambah dan akan berjumlah 4 unit yang masingmasingnya terdiri dari 4 bilik dengan luas $30 \mathrm{~m}^{2}$.

- Gazebo : gazebo akan direnovasi dan ada penambahan sebanyak 3 unit, masing-masingnya dibangun dengan luasan $30 \mathrm{~m} 2$

- Penginapan : kan dibangun 5 penginapan dengan fasilitas didalamnya terdiri dari teras, kamar tidur, dan toilet dengan luas masing-masing $24 \mathrm{~m}^{2}$

- Dermaga : dermaga baru dibangun dengan luas $10 \mathrm{~m} \times 15 \mathrm{~m}=150 \mathrm{~m}^{2}$ sebagai area umum bagi pengunjung

- Jembatan : jembatan dibangun sebagai akses menyebrani danau menuju menara pandang

- Menara Pandang : menara diujung danau akan berfungsi untuk petugas mengawasi kegiatan wisata dan dapat dimanfaatkan oleh pengunjung untuk melihat view kawasan dari atas, serta wisata bird watching

- Papan Petunjuk : disediakan papan petunjuk berisikan informasi, petunjuk arah, larangan dan himbauan berwisata yang tersebar diseluruh kawasan

\section{Analisis Persepsi dan Preferensi Pengunjung}

Analisis persepsi dan preferensi pengunjung akan diolah menggunakan alat analisis Cross Tab dan Importance Performance Analysis. Adapun analisis ini terbagi menjadi beberapa komponen dengan penjelasan pada tabel dibawah ini : 
Tabel 1. Hasil Analisis Persepsi dan Preferensi Pengunjung

\begin{tabular}{|c|c|c|}
\hline Komponen & Jenis Pertayaan & Hasil Analisis \\
\hline \multirow{5}{*}{$\begin{array}{l}\text { Profil dan } \\
\text { Karakteristik } \\
\text { Pengunjung }\end{array}$} & Jenis kelamin & $50,8 \%$ pengunjung berjenis kelamin laki-laki \\
\hline & Usia & $57,5 \%$ pengunjung berusia $17-25$ tahun \\
\hline & Asal daerah & $45 \%$ berasal dari Kabupaten Poso \\
\hline & Jenis pekerjaan & $55 \%$ pengunjung dengan jenis pekerjaan pelajar/mahasiswa \\
\hline & Pendapatan per bulan & $\begin{array}{l}49,2 \% \text { pengunjung dengan pendapatan perbulan }<\mathrm{Rp} \\
2.000 .000\end{array}$ \\
\hline \multirow{10}{*}{$\begin{array}{l}\text { Pola } \\
\text { Kunjungan }\end{array}$} & Tujuan kunjungan & $65,8 \%$ dengan tujuan kunjungan adalah berwisata \\
\hline & $\begin{array}{l}\text { Informasi mengenai objek } \\
\text { wisata }\end{array}$ & $52,5 \%$ mengetahui informasi objek wisata dari media sosial \\
\hline & Daya tarik wisata & $40 \%$ memilih panorama keindahan alam sebagai daya tarik \\
\hline & Rekan berkunjung & $57,5 \%$ datang berkunjung bersama teman \\
\hline & Jumlah kunjungan & $45 \%$ dengan frekuensi $1 x$ kunjungan \\
\hline & Waktu kunjungan & 48,3\% melakukan kunjungan pada hari libur \\
\hline & $\begin{array}{l}\text { Transportasi yang } \\
\text { digunakan }\end{array}$ & $45,8 \%$ menggunakan transportasi pribadi berupa motor \\
\hline & Kegiatan yang dilakukan & $\begin{array}{l}46,7 \% \text { memilih jenis kegiatan rekreasi (bersantai, hunting } \\
\text { foto) }\end{array}$ \\
\hline & Biaya yang dikeluarkan & $\begin{array}{l}\text { 43.3\% memilih } \mathrm{Rp} 16.000 \text { - Rp 40.000/orang untuk satu kal } \\
\text { kunjungan }\end{array}$ \\
\hline & $\begin{array}{l}\text { Fasilitas yang perlu } \\
\text { ditingkatkan }\end{array}$ & $\begin{array}{l}32.5 \% \text { memilih rumah makan/restoran sebagai fasilitas } \\
\text { yang perlu ditingkatkan }\end{array}$ \\
\hline $\begin{array}{l}\text { Kualitas } \\
\text { Pengelolaan }\end{array}$ & $\begin{array}{l}\text { Kuadrat A (Prioritas } \\
\text { utama) }\end{array}$ & $\begin{array}{l}\text { Air bersih, pembuangan sampah, parkir kendaraan, petugas } \\
\text { keamanan, petugas kebersihan, dan petugas parkir. Hal in } \\
\text { juga didukung dengan kondisi eksisting pada kawasan } \\
\text { bahwa beberapa aspek ini memerlukan perhatian lebih dan } \\
\text { perlu di prioritaskan }\end{array}$ \\
\hline
\end{tabular}

Sumber : Hasil Olahan Penulis, 2021

\section{Analisis Sistem Pengelolaan Berdasarkan Benchmark}

Analisis sistem pengelolaan ini akan berdasarkan pada benchmark yang berfokus pada identifikasi kesuksesan kawasan objek wisata yang serupa dan memiliki konsep yang kurang lebih sama. Hal ini dilihat dari aspek pengelolaan dan prinsip ekowisata yang membawa objek wisata pada kondisi yang unggul. Adapun penulis menggunakan Situ Gunung sebagai benchmark pengelolaan ekowisata.

a. Aspek Pengelolaan

Berikut aspek pengelolaan yang diterapkan pada objek wisata Situ Gunung.

- Organisasi : struktur organisasi pada kawasan Situ Gintung terdiri dari kepala resort, pejabat fungsional, tenaga pengamanan hutan lainnya, tenaga kontrak dan $\mathrm{OB}$

- Manajemen : pengelolaan lapangan (divisi tiket, parkir, kebersihan, operasional, pelayanan, dan keamanan), pengawasan terhadap konservasi berupa inventarisasi, perlindungan, pemanfaatan, pengawetan, dan evaluasi kesesuaian fungsi hingga pemberdayaan masyarakat di dalam dan sekitar kawasan

- Sumber Daya Manusia : ketenagarakerjaan dibawah integritas pengelola (Balai Besar Taman Nasional), dalam pelaksanaan dilapangan dilakukan pemberdayaan masyarakat di dalam dan sekitar kawasan untuk membantu peningkatan taraf ekonomi (pekerja lapangan, penjual makanan minuman hingga cinderamata)

- Sarana \& Prasarana : parkir, kebersihan, peribadatan, toilet, wisata petualangan, perkemahan, hiburan, penginapan dan restoran

- Daya Tarik Wisata : rekreasi danau, berkemah, naik perahu rakit, memancing, trekking keliling 
danau, jembatan gantung, dan curug

- Promosi : pemasaran wisata melalui laman resmi (website) dan akun sosial media (instagram, twitter dan facebook) Balai Besar Taman Nasional Gunung Gede Pangrango, juga melalui event, pendidikan lingkungan, kemah konservasi, dll

\section{b. Prinsip Ekowisata}

Penerapan Prinsip Ekowisata pada Kawasan Konservasi berpedoman pada Peraturan yang ditetapkan bersumber dari peraturan lainnya diatur dalam Undang Undang Nomor 51990 Tentang Konservasi Sumber Daya Alam Hayati Dan Ekosistemnya. Pada pengelolaan Danau Tambing, prinsip ekowisata akan diterapkan sebagai berikut:

- Konservasi : Sumber daya alam dan keanekaragaman hayati didalam kawasan ini yang merupakan habitat bagi flora dan fauna. Oleh sebab itu seluruh pihak baik pengelola maupun pengunjung wajib melindungi, mengawetkan dan memanfaatkan secara lestari.

- Edukasi : Pemanfaatan kawasan ini dalam hal pembelajaran yaitu didalamnya terdapat pendidikan lingkungan alam, social dan budaya

- Ekonomi : Keberadaan kawasan wisata ini berkontribusi dalam upaya peningkatan ekonomi lokal dan pembangunan daerah melalui pemberdayaan masyarakat (pekerja dan penjual)

- Kepuasan : Dengan seluruh rangkaian wisata yang ditawarkan, kawasan ini dilengkapi dengan sarana prasarana pendukung mulai dari parkir, kebersihan, peribadatan, toilet, petualangan, perkemahan, hiburan, hingga akomodasi penginapan dan restoran

- Pemberdayaan Masyarakat : Masyarakat lokal dirangkul untuk ikut berpartisipasi dalam kegiatan wisata serta mengangkat kearifan lokal, mulai dari pembangunan, pekerja hingga pedagang pada kawasan wisata yang selain menjual makanan juga aneka ragam kerajinan tangan

\section{Analisis Rencana Biaya Pengelolaan Kawasan}

Analisis ini berhubungan dengan rencana pendapatan dan pengeluaran pengelolaan kawasan. pendapatan terdiri dari pendapatan tiket antara lain tiket masuk, parkir mobil, parkir motor, berkemah, memancing, outbound training dan pendapatan sewa antara lain sewa tenda, wahana bebek, retail, restoran dan penginapan. Tarif ditetapkan berdasarkan Peraturan Pemerintah Nomor 12 Tahun 2014 Tentang Tarif Atas Jenis Penerimaan Negara Bukan Pajak Pada Pariwisata Alam Di Kawasan Pelestarian Alam. Promosi dilakukan pada bulan 0 untuk memperluas dan merangkul wisatawan berkunjung diobjek wisata. Dengan beberapa upaya mulai dari penyebaran informasi wisata melalui media sosial, media cetak hingga penyelenggaraan event wisata. biaya listrik dan air adalah sebesar Rp 2.000.000/bulan, dan mengalami kenaikan pada beberapa bulan tertentu khususnya saat liburan karena jumlah pengunjung yang tinggi tepatnya pada bulan januari, juni, juli, agustus dan desember. Adapun biaya perijinan dan penataan areal berhubungan dengan fasilitas yang akan dibangun terdiri dari lahan parkir hingga beberapa bangunan yang belum tersedia dilokasi wisata dengan total luas perencanaan sebesar $2.927 \mathrm{~m} 2$ sesuai dengan rencana pengembangan ekowisata oleh balai besar taman nasional lore lindu. Untuk sumber dana, pada dasarnya masih sepenuhnya menjadi wewenang pemerintah pusat, dan telah menjadi prioritas pengembangan destinasi wisata sehingga setiap tahun selalu ditingkatkan. Hal merupakan bentuk dukungan pemerintah dalam pengembangan kawasan dan fasilitas pariwisata yang memberikan dampak bagi pariwisata dan ekonomi daerah. dengan demikian, pihak pengelolah wajib memberikan kontribusi nyata adalah dalam bentuk memberikan pemeliharaan dan perawatan terhadap fasilitas yang telah dibangun.

Untuk hasil analisis secara umum dari setiap analisis dapat dilihat pada tabel dibawah ini:

- Analisis Lokasi : objek studi berpotensi untuk dikunjungi wisatawan melihat akses menuju lokasi cukup baik dan dapat dicapai dengan transportasi pribadi maupun umum.

- Analisis Kondisi Eksisting : kondisi eksisting cukup baik tetapi terdapat beberapa fasilitas yang kurang terawat dan belum memenuhi kapasitas dan kebutuhan wisatawan seperti lahan parkir, 
dermaga, toilet, gazebo, kebersihan, listrik hingga air bersih. Belum terdapat struktur yang terintegrasi mengenai pengelolaan, pembiayaan, keamanan, perawatan hingga SOP wisata pada objek wisata

- Analisis Rencana Fisik Berdasarkan Rencana Pengembangan Ekowisata : rencana fisik tersebut berisikan penambahan sarana dan prasarana pelengkap wisata dengan merelokasikan fasilitas yang membutuhkan perbaikan dan penambahan fasilitas yang belum tersedia. Dengan hal ini maka akan menjadi nilai tambah bagi objek wisata Danau Tambing dan dapat menarik minat wisatawan untuk berkunjung.

- Analisis Persepsi dan Preferensi Pengunjung: beberapa hal menjadi prioritas utama dalam segi pengelolaan yang perlu diperhatikan lain air bersih, pembuangan sampah, parkir kendaraan, petugas keamanan, petugas kebersihan, hingga petugas parkir. Adapun menurut responden fasilitas yang perlu ditingkatkan antara lain fasilitas rumah makan, fasilitas kebersihan, fasilitas penginapan hingga tempat perbelanjaan.

- Analisis Sistem Pengelolaan (Benchmark) : kajian dalam penyusunan rencana sistem pengelolaan adalah prinsip ekowisata yaitu aspek konservasi, edukasi, ekonomi, kepuasan pengunjung dan pemberdayaan masyarakat.

- Analisis Rencana Pembiayaan : terdapat rencana pengembangan yang didalamnya terdapat penambahan jenis fasilitas wisata pada objek studi. Dengan ini, dana bersumber dari pemerintah karena pada dasarnya untuk pengadaan sarana prasarana adalah dibawah wewenang pemerintah pusat. Hal merupakan bentuk dukungan pemerintah dalam pengembangan kawasan dan fasilitas pariwisata yang memberikan dampak bagi pariwisata dan ekonomi daerah

\section{KESIMPULAN DAN SARAN}

\section{Kesimpulan}

Merupakan bagian dari Taman Nasional Lore Lindu, Danau Tambing masuk dalam zona pemanfaatan wilayah kerja Resort Tongoa, Bidang PTN Wilayah II Makmur. Zona ini digunakan sebagai pengembangan pariwisata alam dan rekreasi, jasa lingkungan, pendidikan, penelitian dan pengembangan yang menunjang pemanfaatan. Dengan banyaknya potensi wisata, masih terdapat permasalahan terkait pengelolaan mulai dari fasilitas yang kurang terawat bahkan belum mencukupi kebutuhan wisata hingga pengelolaan internal yang belum memiliki struktur organisasi yang terintegrasi berisikan pembagian tugas mengenai pengelolaan, pembiayaan, keamanan, perawatan sarana prasarana dan lain-lain.

Balai Besar Taman Nasional Lore Lindu telah memiliki Rencana Pengembangan Ekowisata Danau Tambing yang didalamnya berisikan penambahan sarana dan prasarana pelengkap wisata dengan merelokasikan fasilitas yang membutuhkan perbaikan dan penambahan fasilitas yang belum tersedia. Hal ini nyatanya sejalan dengan kebutuhan dan permintaan dari pengunjung. Dengan demikian, maka akan menjadi nilai tambah bagi objek wisata Danau Tambing dan dapat menarik minat wisatawan untuk berkunjung.

Penulis menyusun rencana strategi pengelolaan dengan menggunakan aspek pengelolaan juga prinsip ekowisata serta rencana anggaran pembiayaan (budget plan) dan rencana aksi (action plan) untuk dapat diterapkan dalam pengelolaan kawasan. Dengan ini maka diperlukan perhatian dari setiap pihak yang terlibat untuk terus meningkatkan nilai dari objek wisata yang memiliki potensi ini. Setiap upaya harus sejalan dengan peningkatan, pemeliharaan juga kegiatan promosi yang diharapkan dapat menarik dan meningkatkan jumlah pengunjung.

\section{Saran}

Berikut ini merupakan saran mengenai strategi pengelolaan Danau Tambing dengan mempertimbangkan aspek pengelolaan pariwisata dan penerapan prinsip ekowisata pada kawasan konservasi.

a. Aspek Pengelolaan

- Organisasi : merekomendasikan penyusunan struktur organisasi pengelolaan yang terintegrasi 
dan terdiri dari beberapa divisi dengan peran dan tugas masing-masing.

- Manajemen : Menyusun dokumen perencanaan yang terorganisir dan sesuai dengan Standard Operating Procedure (SOP). Melaksanakan pemeliharaan maintenance, kebersihan, hingga program keselamatan kesehatan kerja. Menetapkan tata tertib, pemanfaaan dan peningkatan kualitas lingkungan

- Sumber Daya Manusia : Menambah sumber daya manusia salah satunya sebagai bentuk pemberdayaan masyarakat lokal, melaksanakan program peningkatan kualitas sumber daya manusia, dan bekerja dibawah Standard Operating Procedure (SOP) yang berlaku.

- Sarana dan Prasarana : Peningkatan kuantitas dan kualitas sarana dan prasarana yang diperlukan, terlihat dari hasil analisis persepsi dan preferensi pengunjung yang dapat dijadikan saran dan rekomendasi sesuai dengan pengalaman wisata.

- Daya Tarik Wisata : Menjaga daya tarik wisata yang telah ada seperti keindahan alam, flora dan fauna, menambah jenis kegiatan wisata, mengadakan event dan atraksi budaya lokal yang dapat menjadi nilai tambah bagi objek wisata

- Promosi : Melaksanakan upaya promosi yang lebih luas agar dapat menjangkau lebih banyak lagi wisatawan. Hal ini dapat dilakukan melalui media sosial, media massa, media cetak hingga pengadaan kegiatan rutin berupa pameran atau event tertentu

\section{b. Prinsip Ekowisata}

- Konservasi : Melakukan pengawasan untuk menjaga keutuhan kawasan konservasi dengan menerapkan batas yang jelas antara ekowisata dan konservasi, memberikan edukasi dan melibatkan masyarakat lokal serta wisatawan mengenai pentingnya menjaga area konservasi hutan. Menyebarkan papan informasi dan larangan mengenai tata tertib wisata pada kawasan konservasi.

- Edukasi : Memberi edukasi kepada wisatawan terlebih dengan tujuan utama wisata melakukan penelitian, pendidikan, menyediakan tenaga ahli yang pada bidangnya dapat menjadi tourguide, melakukan penambahan atribut wisata untuk memperluas pengetahuan wisatawan mengenai ekowisata.

- Ekonomi : Memberikan wadah untuk terciptanya sumber dan peningkatan pendapatan ekonomi lokal. Adanya peningkatan prasarana lingkungan pada masyarakat disekitar objek wisata, pengembangan wisata melibatkan masyarakat dan menjadi sumber pendapatan dan peningkatan ekonomi, masyarakat memberikan produk budaya dan seni, masyakarat bersedia terlibat dalam pengembangan kawasan wisata

- Kepuasan : Mengedepankan aspek pengelolaan yang memberikan kepuasan bagi pengunjung dimulai dari peningkatan atribut, fasilitas hingga pelayanan wisata. Memberikan pengalaman yang menarik pada pengunjung mengenai jasa dan produk yang ditawarkan.

- Pemberdayaan Masyarakat : Merangkul dan memberikan edukasi bagi masyarakat lokal untuk menjadi bagian dari aktor wisata mulai dari berperan sebagai pekerja lepas, penyedia jasa wisata, sarana UMKM, atraksi budaya, kuliner hingga memproduksi produk yang mengangkat kearifan lokal

c. Rencana Anggaran Pembiayaan (Budget Plan)

Tabel 2. Rencana Anggaran Pembiayaan

\begin{tabular}{clccc}
\hline No & & Keterangan & & Total \\
\hline 1 & Tiket masuk & $\mathrm{Rp}$ & $339,105,000$ \\
\hline 2 & Berkemah & $\mathrm{Rp}$ & $197,255,000$ \\
\hline 3 & Parkir mobil & $\mathrm{Rp}$ & $24,000,000$ \\
\hline 4 & Parkir motor & $\mathrm{Rp}$ & $60,000,000$ \\
\hline 5 & Memancing & $\mathrm{Rp}$ & $3,900,000$ \\
\hline
\end{tabular}




\begin{tabular}{clcc}
\hline No & \multicolumn{1}{c}{ Keterangan } & & \multicolumn{1}{c}{ Total } \\
\hline 6 & Outbound training & $\mathrm{Rp}$ & $1,800,000$ \\
\hline 7 & Sewa wahana air (bebek-bebek) & $\mathrm{Rp}$ & $120,000,000$ \\
\hline 8 & Sewa retail & $\mathrm{Rp}$ & $14,400,000$ \\
\hline 9 & Sewa restoran & $\mathrm{Rp}$ & $7,200,000$ \\
\hline 10 & Sewa penginapan & $\mathrm{Rp}$ & $7,200,000$ \\
\hline 11 & Biaya perijinan dan penataan areal & $\mathrm{Rp}$ & $14,867,973,000$ \\
\hline Pendapatan pertahun & $\mathrm{Rp}$ & $15,648,833,000$ \\
\hline No & & & Total \\
\hline 1 & Biaya perijinan dan penataan areal & $\mathrm{Rp}$ & $14,867,973,000$ \\
\hline 2 & Biaya pengadaan wahana air & $\mathrm{Rp}$ & $42,500,000$ \\
\hline 3 & Biaya promosi & $\mathrm{Rp}$ & $10,000,000$ \\
\hline 4 & Upah staff & $\mathrm{Rp}$ & $192,000,000$ \\
\hline 5 & Biaya pemeliharaan & $\mathrm{Rp}$ & $72,000,000$ \\
\hline 6 & Biaya peningkatan SDM & $\mathrm{Rp}$ & $36,000,000$ \\
\hline 7 & Biaya listrik dan air & $\mathrm{Rp}$ & $28,000,000$ \\
\hline 8 & Biaya ATK & $\mathrm{Rp}$ & $30,000,000$ \\
\hline 9 & Biaya operasional (renovasi \& service ringan) & $\mathrm{Rp}$ & $6,000,000$ \\
\hline Pengeluaran pertahun & $\mathrm{Rp}$ & $15,284,473,000$ \\
\hline & TOTAL KEUNTUNGAN & $\mathrm{Rp}$ & $364,360,000$ \\
\hline
\end{tabular}

Sumber : Hasil Olahan Penulis, 2021

d. Rencana Aksi (Action Plan)

Tabel 3. Rencana Aksi

\begin{tabular}{|c|c|c|c|c|c|c|}
\hline \multirow{2}{*}{ Rencana Program Kerja dan Kegiatan } & \multirow{2}{*}{ Instansi } & \multicolumn{5}{|c|}{ Tahun } \\
\hline & & I & II & III & IV & $\mathrm{V}$ \\
\hline \multicolumn{7}{|l|}{ Pekerjaan Fisik } \\
\hline $\begin{array}{l}\text { Penataaan/pembangunan area parkir, air bersih, } \\
\text { dan prasarana persampahan }\end{array}$ & BBTNLL/DISPARBUD KAB & & & & & \\
\hline Pembangunan rumah makan/restoran & BBTNLL/DISPARBUD KAB & & & & & \\
\hline Pembangunan area retail/UMKM & BBTNLL/DISPARBUD KAB & & & & & \\
\hline Pembangunan pondok penginapan & BBTNLL/DISPARBUD KAB & & & & & \\
\hline Pembangunan pusat informasi wisata & BBTNLL/DISPARBUD KAB & & & & & \\
\hline $\begin{array}{l}\text { Pembangunan fasilitas penunjang (toilet, gazebo, } \\
\text { menara pandang, dan jembatan) }\end{array}$ & BBTNLL/DISPARBUD KAB & & & & & \\
\hline \multicolumn{7}{|l|}{ Pengelolaan/Manajemen } \\
\hline Pembangunan perencanaan investasi wisata & BBTNLL/DISPARBUD KAB & & & & & \\
\hline $\begin{array}{l}\text { Penyusunan organisasi pengelolaan secara } \\
\text { terintegrasi }\end{array}$ & BBTNLL & & & & & \\
\hline Penyusunan rencana pemasaran (promosi) & BBTNLL/DISPARBUD KAB & & & & & \\
\hline $\begin{array}{l}\text { Pelatihan pengelolaan dan pemberdayaan } \\
\text { masyarakat }\end{array}$ & BBTNLL & & & & & \\
\hline $\begin{array}{l}\text { Pelatihan manajemen bencana pada destinasi } \\
\text { wisata }\end{array}$ & BBTNLL & & & & & \\
\hline \multicolumn{7}{|l|}{ Acara/Event } \\
\hline Festival budaya tradisional tahunan & BBTNLL/DISPARBUD KAB & & & & & \\
\hline National birdwatching & BBTNLL/DISPARBUD KAB & & & & & \\
\hline Wildnature fotografi & BBTNLL/DISPARBUD KAB & & & & & \\
\hline
\end{tabular}

Sumber : Hasil Olahan Penulis, 2021 


\section{REFERENSI}

Allaby, M. (2010). A dictionary of Ecology. Oxford University Press.

Cooper, C. F. (2005). Tourism; Principle and Practive, Third Edition. Harlow: Prentice Hall.

Sandy, I. M. (1985). Republik Indonesia Geografi Regional. Jakarta: Puri Margasari.

Sastrayuda, G. (2015). Strategi Pengembangan dan Pengelolaan Resort. Konsep Pengembangan Kawasan Agrowisata, 6.

Smith. (1989). Karakteristis Pengunjung. Jakarta: Ghalia Indonesia.

Smith, J. (1989). Karakteristik Pengunjung. Jakarta: Ghalia Indonesia.

Supriatna, J. (2014). Penelitian Strategis dalam Pengembangan Konservasi. Lingkungan dan Pembangunan, Lingkungan dan Pembangunan.

Terry. (2010). Dasar-Dasar Manajemen. Jakarta: PT Bumi Aksara.

Warren, D. (1992). Indigenous Know-ledge, Biodiversity Conservation and Development. Paperon International Conference on Conservation of Biodivercity.

Dokumen Rencana Induk Pengembangan Ekowisata dan DED Pilot Ekowisata di Taman Nasional Lore Lindu, Sulawesi Tengah

Peraturan Menteri Dalam Negeri No.33 Tahun 2009 tentang Pedoman Pengembangan Ekowisata

Peraturan Pemerintah Nomor 12 Tahun 2014 tentang Tarif Atas Jenis Penerimaan Negara Bukan Pajak Pada Pariwisata Alam Di Kawasan Pelestarian Alam

Undang Undang Nomor 51990 Tentang Konservasi Sumber Daya Alam Hayati Dan Ekosistemnya 